\title{
19. REGIONAL HEAT FLOW IN THE VICINITY OF THE CHILE TRIPLE JUNCTION CONSTRAINED BY THE DEPTH OF THE BOTTOM-SIMULATING REFLECTION ${ }^{1}$
}

\author{
Nathan L. Bangs ${ }^{2}$ and Kevin M. Brown ${ }^{3}$
}

\begin{abstract}
The depth of the bottom-simulating reflection (BSR) observed from seismic-reflection data throughout the Chile Triple Junction region is used to estimate the temperature at the base of the gas hydrate stability field and to calculate the regional pattern of heat flow. Brown et al. (this volume) calibrate temperature-depth conditions at the BSR, which we use to estimate temperatures from BSR depths. Seismic velocity information needed to estimate BSR depths from seismic arrival times, and thermal conductivity data are provided by Leg 141 drilling.

The heat-flow pattern varies greatly across the Darwin Fracture Zone. North of the Darwin F.Z., along seismic Line 743, heat flow shows a seaward decreasing trend across the accretionary wedge from $80 \mathrm{~mW} / \mathrm{m}^{2} 30 \mathrm{~km}$ from the wedge toe, to $40 \mathrm{~mW} / \mathrm{m}^{2}$ $10 \mathrm{~km}$ from the wedge toe. The decrease in heat flow is opposite to what is expected from the age variation of the underlying oceanic crust and is interpreted to be low because of recent tectonic thickening of the accretionary complex. South of the fracture zone, heat flow reflects the young age of the underlying oceanic crust as it shows a seaward increasing trend from $~ 80 \mathrm{~mW} / \mathrm{m}^{2}$ in the mid slope area to as high as $200 \mathrm{~mW} / \mathrm{m}^{2}$ at the toe of the trench slope, increasing with decreasing age of the crust. Heat flow contours south of the Darwin F.Z. parallel the Chile Ridge, except near the deformation front; where heat flow contours are oriented along the deformation front. We attribute the heat flow pattern near the deformation front to advective heat transport from pore fluids escaping near the wedge toe. Tectonic thickening does not have as noticeable an effect on the heat flow south of the Darwin F.Z. as north of it, and tectonic thickening may be less active near the triple junction.
\end{abstract}

\section{INTRODUCTION}

The Chile Triple Junction is an ideal location to examine the effects of subduction of a seafloor spreading ridge. The Chile Ridge initially collided with the South American continent approximately $14 \mathrm{Ma}$, near Tierra del Fuego, and since then, segments of the Chile Ridge have been subducted in a progression from south to north. The currently subducting segment of the Chile Ridge lies just north of the Taitao Peninsula, between the Darwin and Taitao fracture zones. North of the Darwin Fracture Zone (F.Z.), the ridge is offset to the west and is predicted to collide with the Chile margin in approximately 1 m.y. The orientation of the spreading ridge is slightly oblique to the trench (Fig. 1) and ridge subduction has advanced to varying degrees from the Taitao F.Z., where subduction began $\sim 100,000$ yr ago, to the Darwin F.Z., where the ridge is expected to be subducted in just over $\sim 100,000$ yr. Consequently, by examining the margin from south to the north, we can study the progressive effects of ridge subduction on the overriding continental margin.

Of the many effects of ridge collision, one of the most extreme is the effect of the Chile Ridge on the geothermal structure. Heat flow is expected to be extremely high with the subduction of young oceanic crust. Heat flow is predicted to be nearly four times greater south of the Darwin F.Z. than to the north (Cande et al., 1987). Furthermore, mid-ocean spreading ridge systems are known to have extremely vigorous hydrothermal systems associated with them, which are driven by the convective cooling of the hot, young crust of the seafloor spreading center. Hydrothermal circulation is expected to become disrupted and diminish as the spreading ridge passes beneath the margin and fluid flow is restricted by the overlying accretionary complex that comprises the toe of the slope.

\footnotetext{
'Lewis, S.D.. Behrmann, J.H.. Musgrave, R.J., and Cande, S.C. (Eds.), 1995. Proc. ODP. Sci. Results, 141: College Station. TX (Ocean Drilling Program).

Institute for Geophysics. The University of Texas at Austin, 8701 Mopac Expressway, Austin, TX 78759-8397, U.S.A.

${ }^{3}$ Scripps Institution of Oceanography, University of California at San Diego, La Jolla, CA 92093-0220, U.S.A.
}

The bottom-simulating reflection (BSR) in southern Chile is well suited for a regional examination of the geothermal structure. It has long been thought that the BSR marks the base of the hydrate stability field and that the depth to the BSR is thermally controlled (Shipley et al., 1979; Kvenvolden and Barnard, 1993). Examination of the BSR by Bangs et al. (this volume) indicates that the BSR is caused by free gas at the base of hydrate-bearing sediment, and confirms that the BSR marks the base of the hydrate stability field. Brown et al. (this volume) present temperatures recorded in the drill holes from WSTP, ADARA, and downhole logging at the BSR, which calibrate the BSR with the pressures and temperatures associated with the base of the hydrate stability field. From these results and improved velocities from downhole sonic logs good estimates of depths to the BSR are possible, and can be used to also estimate the temperature at the BSR and the regional pattern of heat flow. Heat flow profiles estimated from the BSR across other accretionary complexes have been useful for examining the thrust activity within the accretionary complex and pore fluid migration out of accretionary wedges (Yamano et al., 1982; Minshull and White, 1989; Davis et al., 1990; Ferguson et al., 1993).

The purpose of this study is to use the depth to the BSR to estimate heat flow in the vicinity of the Chile Triple Junction. We examine the regional heat flow from south to north to qualitatively interpret the effects of spreading ridge subduction on the overriding margin through the effects on heat flow.

\section{HEAT FLOW CALCULATED FROM THE BSR}

\section{Heat Flow Calculation}

The method of calculating heat flow from the depth to the BSR is based on methods described by Yamano et al. (1982), Macleod (1982), Hyndman et al. (1993), and followed by Cande et al. (1987) for their earlier estimate of heat flow from the BSR for the same region. As outlined by Hyndman et al. (1993), factors required for estimates of heat flow from the BSR include the following: (1) the arrival time of the BSR, (2) the average seismic velocity to the BSR to calculate the depth to the BSR, (3) the relationship between the BSR depth and temperature based on the hydrate pressure-temperature stability field, (4) the temperature at the seafloor to establish the temperature gradient 


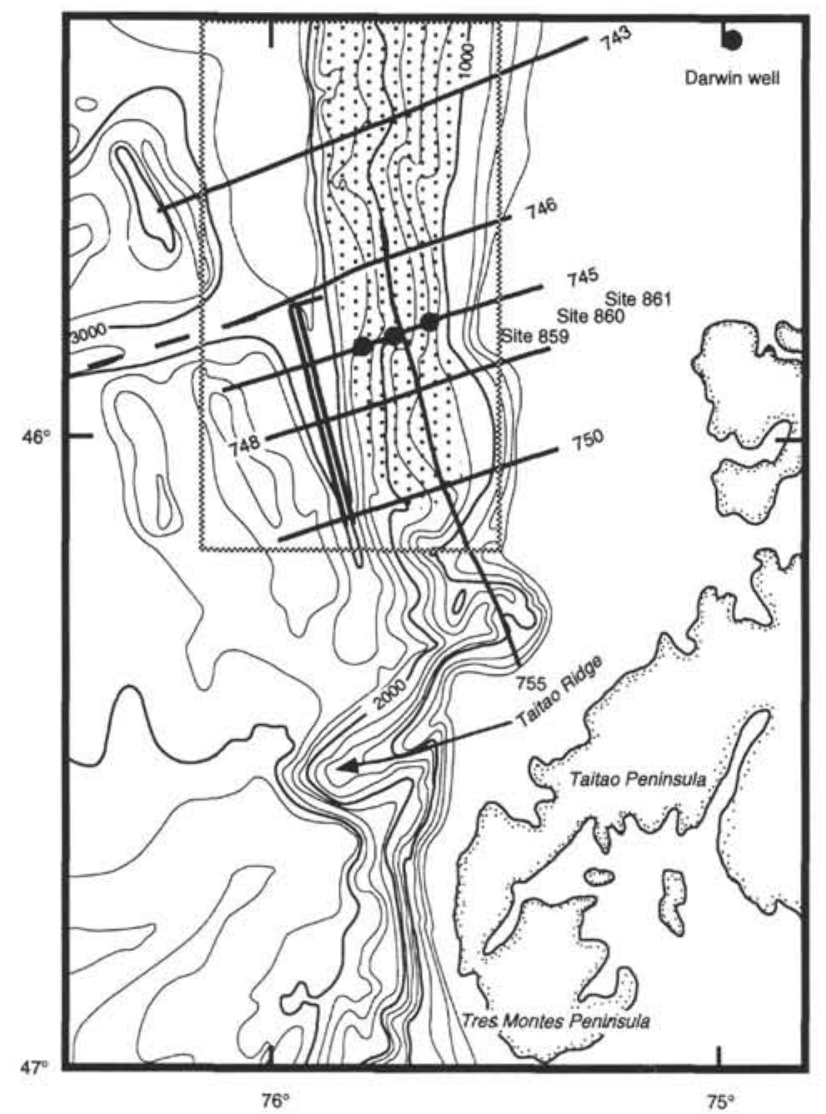

Figure 1. Bathymetric map of the Chile Triple Junction showing the location of Leg 141 Sites 859, 860, and 861 and the seismic reflection lines that have an identifiable BSR. The stippled area outlines where the BSR is found. Rectangle shows the area of detail in Figures 3-6.

between the BSR and seafloor, and (5) the thermal conductivity of the sediment between the BSR and seafloor.

\section{Sub-bottom Depth of the BSR}

The depth to the BSR was estimated from seismic-reflection data in the vicinity of the triple junction, which were acquired aboard the Conrad in 1988 as part of the site survey for drilling (Bangs et al., 1992). A large contribution to uncertainty in heat flow determined from the BSR is the determination of the depth to the BSR. Therefore, careful examination of the arrival times and seismic velocities is needed for accurate determination of thermal gradients.

The BSR is generally easily recognized in the seismic section. Figure 2 shows Line 745 acquired along the transect of the three drill sites $(859,860$, and 861). At Sites 859 and 860 , the reflection has relatively higher amplitude than that at Site 861 . The BSR is a discontinuous, phase-reversed, seafloor-parallel event with amplitude up to one-third the amplitude of the seafloor. It lies between $\sim 100 \mathrm{mbsf}$ at Site 859 and $\sim 250 \mathrm{mbsf}$ at Site 861 . The BSR along Line 748 was sufficiently shallow in several locations that a source-generated bubble pulse $100 \mathrm{msec}$ below the primary seabottom reflection interferes with the BSR. The BSR was examined closely along this line to assure the event was accurately distinguished from seafloor bubble pulses.

The BSR depth was determined from the measured arrival times of the BSR and seafloor reflections. A $25 \mathrm{~ms}$ window around the seafloor and BSR events was searched to determine the maximum (or in the case of the BSR the minimum) amplitude, to assure consistent interpretation of arrival times. Depth to the BSR was obtained by calculating the depth to the seafloor, assuming a water velocity of $1.49 \mathrm{~km} / \mathrm{s}$ and adding the estimated depth below seafloor of the BSR.

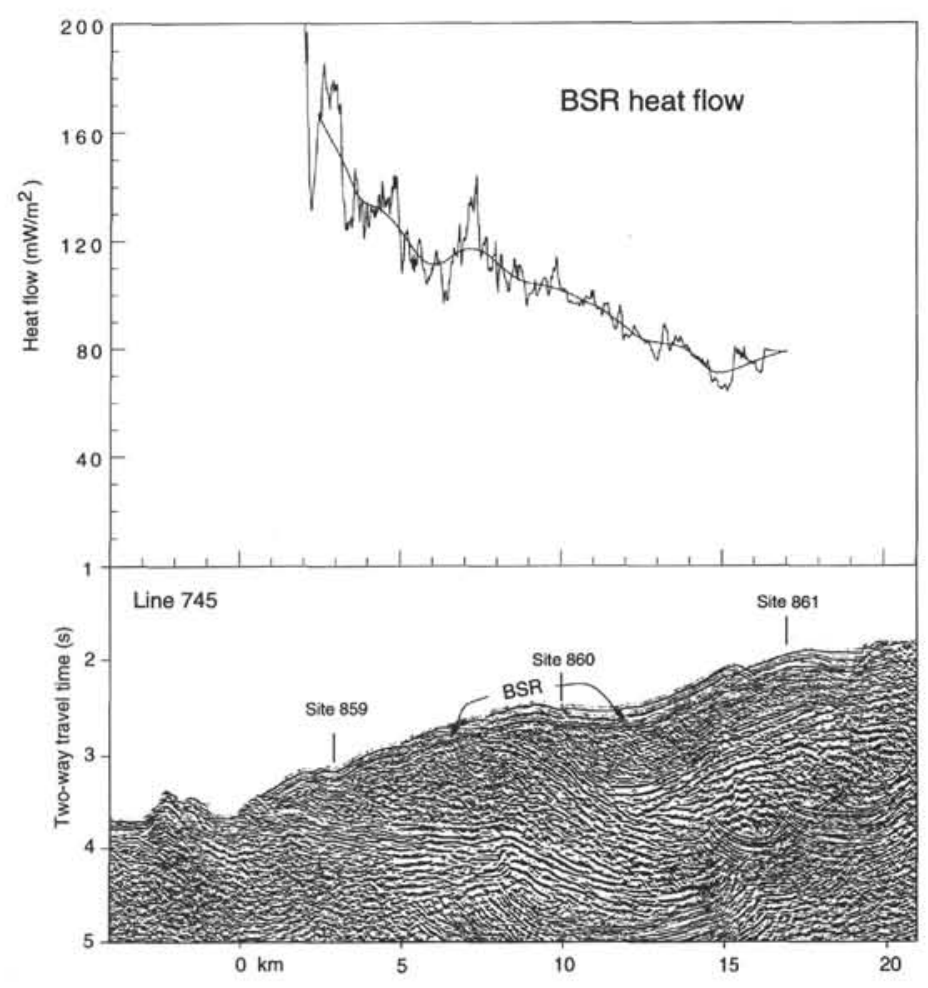

Figure 2. Heat flow profile estimated from the depth to the BSR on seismic Line 745. Both raw and smoothed heat flow estimates are shown. Sites 859 . 860 , and 861 are located on this line and were drilled through the interval that produced the BSR. The BSR lies between 100 to 250 mbsf, between Sites 859 to 861 .

The velocity of the interval between the seafloor and the BSR is a common source of uncertainty in estimates of BSR depths. Velocity was estimated based on sonic logs at Sites 859 and 860 , as these are the only available information on the velocity in the near-seabottom section. From these data, we approximate the velocity with depth between the seafloor and the BSR from the linear function $V=1650+2.33 Z$, where $\mathrm{V}$ is the velocity in $\mathrm{m} / \mathrm{s}$ and $\mathrm{Z}$ is the depth below seafloor in meters. The depth to the BSR in the vicinity of the triple junction was estimated from six seismic lines. Other seismic lines examined south of Line 750, near Site 863, have no BSR. A smooth surface representing the depth to the BSR across the area covered by these lines was calculated from the depth data (Fig. 3). In places, at Site 860 and 861 for example, depths shown in Figure 3 are $10-20 \mathrm{~m}$ shallower than estimated. The fitted surface depicts the regional trends in depth to the BSR but in doing so has removed some localized depth variations.

We did not consider the effect of large quantities of hydrate on the velocity of the material overlying the BSR. Although hydrate has a much higher seismic velocity than shallow sediment $(3.8 \mathrm{~km} / \mathrm{s}$ vs. $\sim 1.8 \mathrm{~km} / \mathrm{s}$ ) and its presence could increase the average velocity between the BSR and sea bottom, quantities of hydrate where it was drilled were usually less than a few percent pore space (Behrmann, Lewis, Musgrave, et al., 1992), and, overall, too small to increase the average sediment velocity significantly. We also do not expect the hydrate is of sufficient quantity to significantly affect the thermal conductivity of the sediment between the BSR and seafloor.

\section{Geothermal Gradients and Heat Flow}

The appropriate hydrate stability field describing pressure and temperature at the BSR has been somewhat controversial, largely because of the uncertainty in the hydrate composition (Hyndman et al., 1992). Brown et al. (this volume) examine the depth and tempera- 
Depth to the BSR ( mbsf )

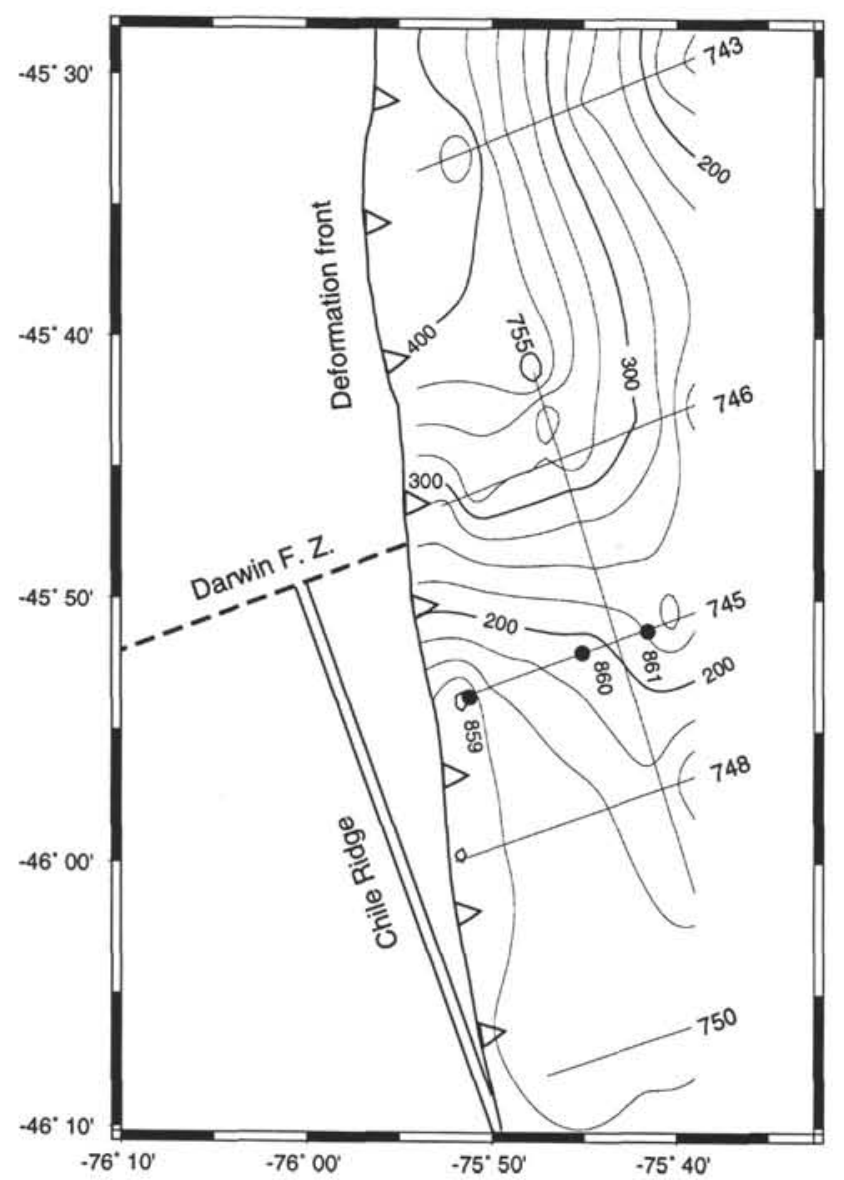

Figure 3. Estimate of the depth below seafloor of the BSR is displayed throughout the triple junction region. Contour interval is $25 \mathrm{~m}$. Thin straight lines show the segments of the seismic lines that have an identifiable BSR. Depths range from as much as $400 \mathrm{mbsf}$ near the deformation front on Line 743 to as shallow as $100 \mathrm{mbsf}$ at the toe of Lines 745 and 748 .

ture data acquired during Leg 141 drilling. Assuming hydrostatic pore fluid pressure, they show that the methane-seawater curve best estimates the depth-temperature relationship at the base of the hydrate stability field along the BSR. The depth-temperature relationship established by these data assumes hydrostatic pore fluid pressure. Little indication of overpressured pore fluid is seen in these sediments, such as high sediment porosities, and hydrostatic pore-fluid pressures should be a valid assumption. The results of temperature estimates at the BSR are displayed in Figure 4. Temperatures range from $11^{\circ} \mathrm{C}$ along the landward edge of Line 743 to $20^{\circ} \mathrm{C}$ along the seawardmost edge of the BSR on Lines 745-743.

Seawater temperatures were measured during descent of the WSTP and ADARA temperature tools during Leg 141 and were consistently $2.2^{\circ} \mathrm{C}$ at the seabottom.

The thermal gradient and heat flow maps (Figs. 5 and 6) show the geothermal structure in the vicinity of the triple junction. The heat flow map was constructed from the geothermal gradient data assuming a constant value of $1.2 \mathrm{~mW} / \mathrm{m}^{\circ} \mathrm{C}$ for the thermal conductivity in the interval between the BSR and the seafloor. Leg 141 cores provided a total of 135 thermal conductivity measurements within the first 250 mbsf at Sites 859, 860, and 861, and these data were averaged in each of the holes. Thermal conductivity varies considerably more within each hole than between sites, so we have not tried to distinguish different thermal conductivities for different parts of the slope. The $1.2 \mathrm{~m}$
Temperature at the BSR $\left({ }^{\circ} \mathrm{C}\right)$

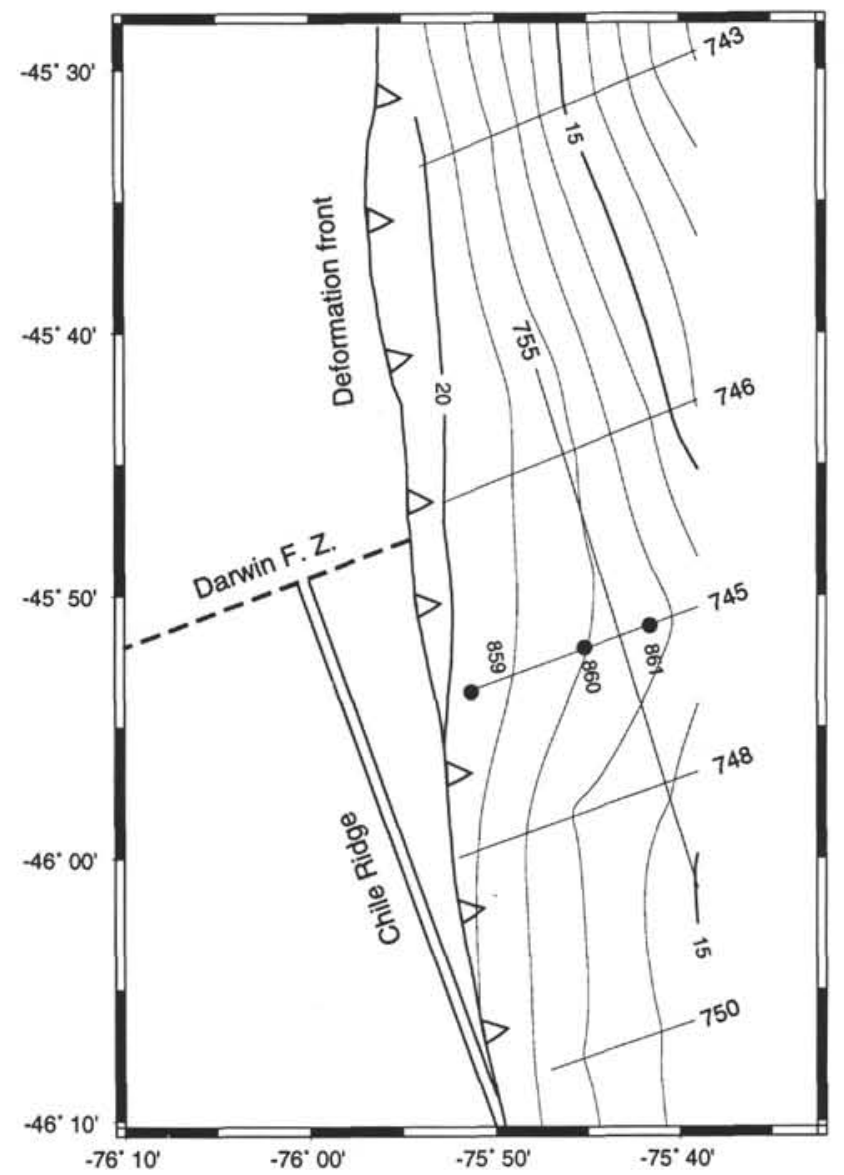

Figure 4. Temperature estimates from the depth below seafloor of the BSR in ${ }^{\circ} \mathrm{C}$ in the vicinity of the triple junction. Contour interval is $1^{\circ}$. Temperatures were estimated from depths using the stability curve for hydrate with a seawater/methane composition, as reported by Brown et al. (this volume).

$\mathrm{W} / \mathrm{m}^{\circ} \mathrm{C}$ value is an average from Sites 859,860 , and 861 . Thermal conductivity values at Site 863 are somewhat higher than the other sites, and these data were not used in calculating this average.

The heat flow results show the strong influence of the hot, young crust that underlies the mapped area. The most striking result displayed by the heat flow map in Figure 6 was the high heat flow at the toe of the slope. The maximum heat flow is estimated to exceed $200 \mathrm{~mW} / \mathrm{m}^{2}$ at the seawardmost extent of the BSR on Lines 745 and 748. Comparison of the heat flow determined from the BSR and surface heat flow measurements of Cande et al. (1987) shows two of the six heat flow probe measurements correspond well with the results presented here (Fig. 6). The lowest probe value of $90 \mathrm{~mW} / \mathrm{m}^{2}$ lies in the trench, seaward of the BSR, and is not directly comparable with heat flow estimates from the BSR. Three of the heat flow probe measurements (316, 343 , and $162 \mathrm{~mW} / \mathrm{m}^{2}$ ) that do overlap with the BSR are higher than what was predicted from the BSR. This difference is attributed to the change in thermal gradient with depth below seafloor. The probe measured gradients over a few meters from the seafloor, while thermal gradients derived from the BSR are gradients over an interval that extends much deeper.

The pattern of heat flow differs distinctly north and south of the Darwin F.Z. and is believed to reflect the differences in heat flux from the oceanic crust that underlies segments on either side of the fracture zone. North of the Darwin F.Z., heat flow is lower (approximately 60 $\mathrm{mW} / \mathrm{m}^{2}$ compared to values of 80 to $200 \mathrm{~mW} / \mathrm{m}^{2}$ south of the fracture 


\section{Thermal Gradient $\left({ }^{\circ} \mathrm{C} / \mathrm{Km}\right)$}

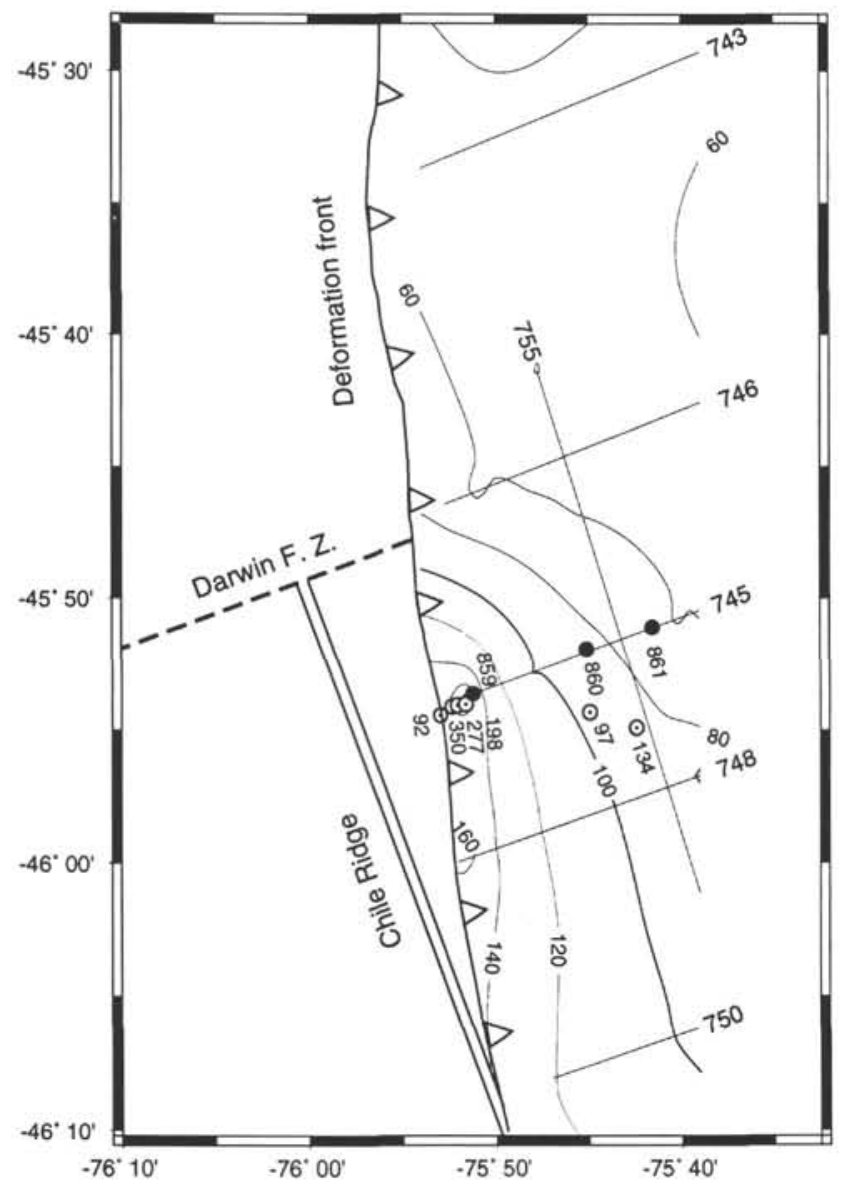

Figure 5. Geothermal gradient in ${ }^{\circ} \mathrm{C} / \mathrm{km}$ for the Chile Triple Junction region, as estimated from the depth to the BSR. Contour interval is $20^{\circ} \mathrm{C} / \mathrm{km}$. The gradient is particularly high south of the Darwin F.Z. where young oceanic crust lies near or beneath the deformation front.

zone) and more uniform than the pattern to the south. South of the Darwin F.Z. heat flow shows a distinct trend, decreasing by a factor of 2-3 from the toe of the slope to the upper slope. High heat flow values south of the Darwin F.Z. and the large decrease with increasing crustal age are consistent with the age versus heat flow relationship of young oceanic crust (Parsons and Sclater, 1977), while lower values and smaller changes with crustal age, as observed north of the Darwin F.Z., are consistent with older cooler oceanic crust.

Contours of constant heat flow change orientation across the lower slope away from the deformation front (Figure 6). Heat flow contours near the toe $\left(>140 \mathrm{~mW} / \mathrm{m}^{2}\right)$ are oriented roughly along the deformation front. Contours of the lower heat flow values $\left(<100 \mathrm{~mW} / \mathrm{m}^{2}\right)$ between Lines 745,748 , and 750 are oriented slightly oblique to the deformation front and parallel the Chile Ridge.

\section{DISCUSSION}

Based on previous studies of accretionary complexes and the midocean seafloor spreading systems, we suggest that three main factors interact to form the complex pattern of heat flow along the lower trench slope in the vicinity of the triple junction. First, heat flow from the young oceanic crust is expected to be high and dominate the heat flow pattern in the triple junction region as previously recognized by Cande et al. (1987). Unfortunately the component of heat flow from the
Heat Flow $\left(\mathrm{mW} / \mathrm{m}^{2}\right)$

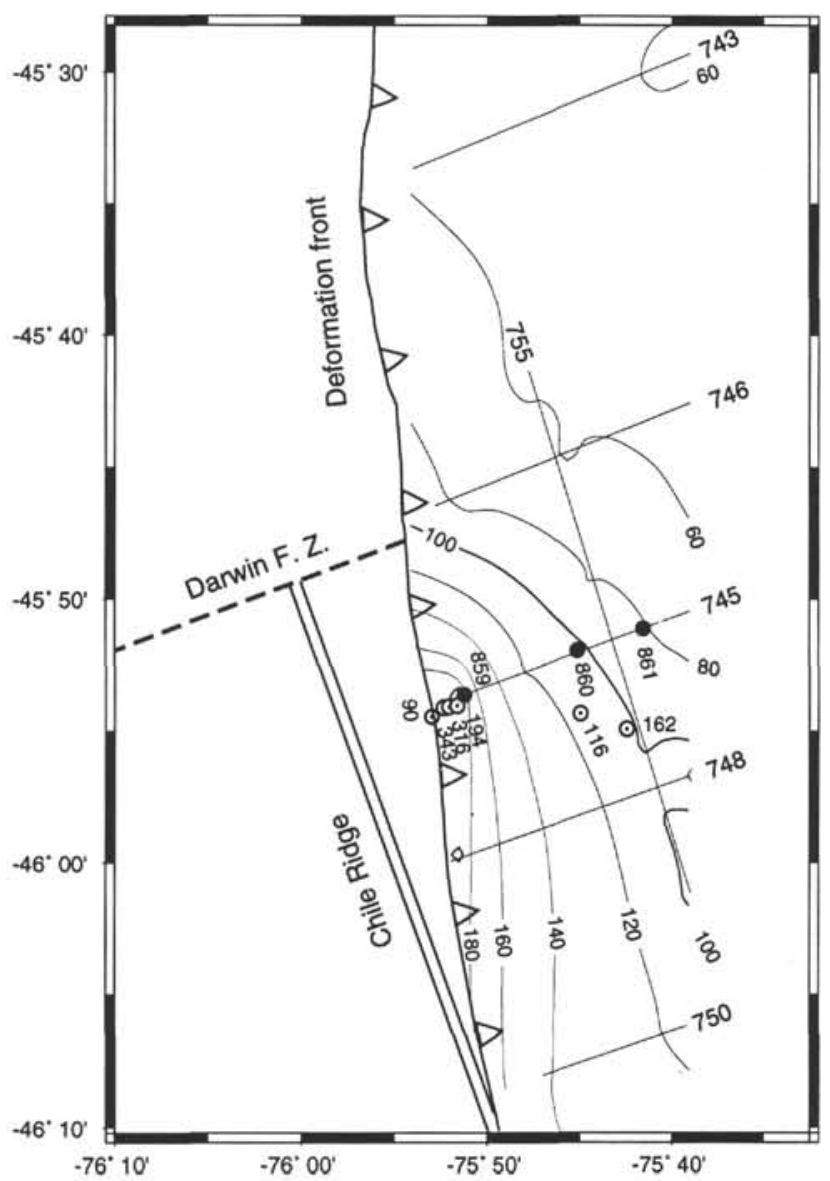

Figure 6. Heat flow estimates (in $\mathrm{mW} / \mathrm{m}^{2}$ ) estimated from the depth to the BSR in the triple junction region. Heat flow values were calculated from the geothermal gradient shown in Figure 5, using an estimated thermal conductivity of $1.2 \mathrm{~W} /{ }^{\circ} \mathrm{Cm}$. Also shown by the dots are heat-flow probe measurements reported by Cande et al. (1987). Heat flow is particularly high near the toe of the margin, where hydrothermal circulation is believed to be extremely active.

oceanic crust in this area is not well known. The Parsons and Sclater (1977) conductive cooling model predicts heat flow based on crustal age to be approximately 5 times greater across Line 743 , and between 2 and 3 times greater along Line 745 than what we estimate from the BSR. Cooling of the oceanic crust by means other than conductive cooling prior to subduction beneath the margin is likely to have occurred, but the extent is unknown and the crustal component of heat flow in this area is difficult to predict. There are also few heat flow measurements seaward of the deformation front that can be used to characterize the crustal input. Although the crustal component is not known we expect it to be large and decrease with increasing crustal age.

A second factor contributing to the heat flow pattern is tectonic thickening within accretionary complexes, which has been documented in other areas to lower geothermal gradients significantly by overthrusting deeper, warmer sediments over cooler, shallower ones (e.g., Langseth et al., 1990; Ferguson et al., 1993). This could potentially lower the regional heat flow within the accretionary complex along the trench slope.

The third factor is fluid circulation, which is expected to be active within both the seafloor spreading center and accretionary complex settings and may have measurable effects on a regional and local scale. Upward advection of warm fluids will elevate geothermal 


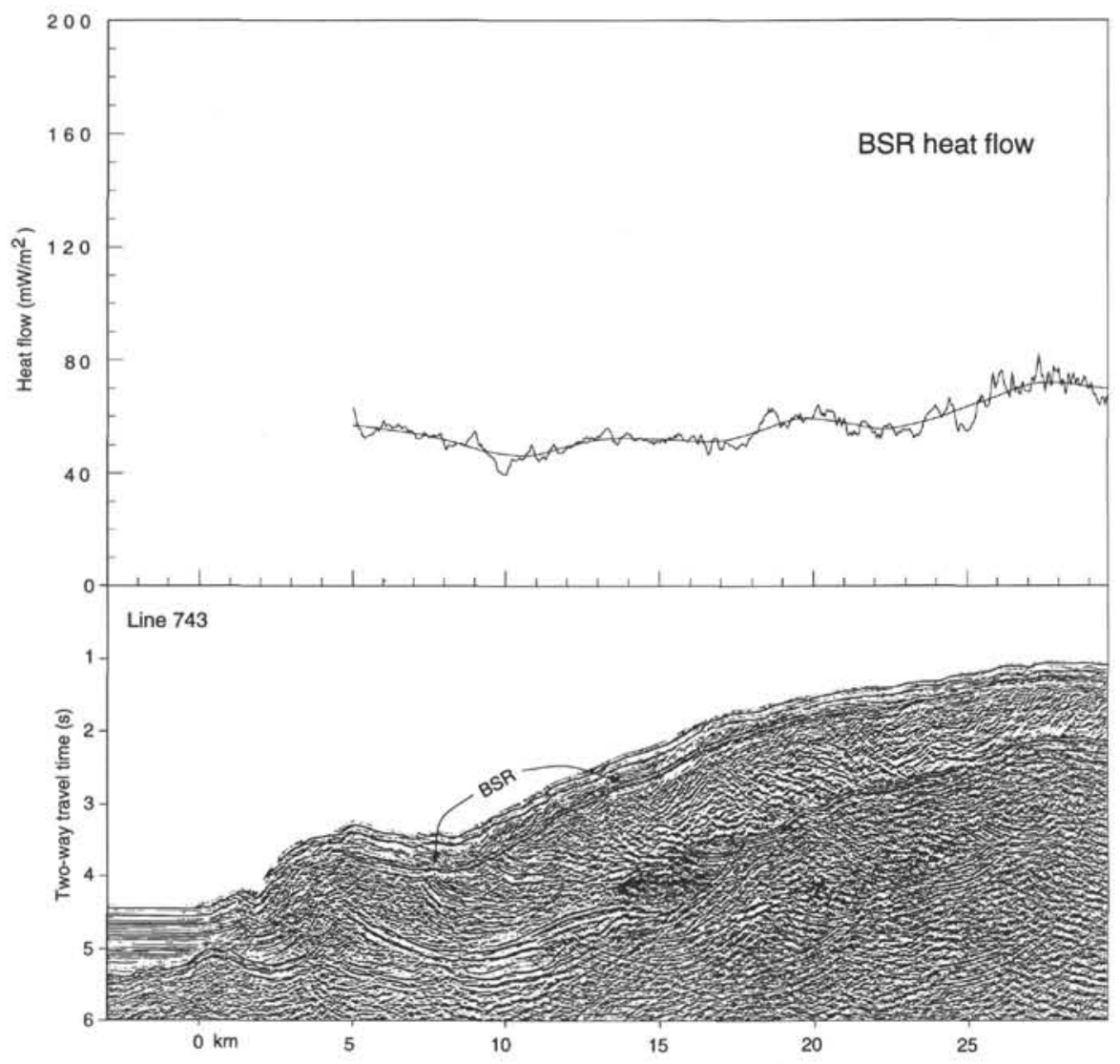

Figure 7. Heat flow profile estimated from depth to the BSR on seismic Line 743 (located in Fig. 1). Both raw and smoothed heat flow estimates are shown. Heat flow decreases greatly from the midslope area at $\sim 30 \mathrm{~km}$ from the deformation front to within $10 \mathrm{~km}$ of the deformation front.

gradients as observed in other accretionary complexes (e.g., Langseth et al., 1990).

The heat flow pattern from the BSR shows two distinct regions separated by the Darwin Fracture Zone. Line 743 (Fig. 7) lies $~ 22 \mathrm{~km}$ north of the Darwin F.Z. where 2 m.y. old crust is subducting beneath the lower slope. Here heat flow may be characteristic of other segments of the margin that are not near the Chile Ridge. Overall, heat flow across Line 743 decreases from $\sim 80 \mathrm{~mW} / \mathrm{m}^{2}$ along the upper slope, to just over $40 \mathrm{~mW} / \mathrm{m}^{2} 10 \mathrm{~km}$ seaward of the wedge toe (Fig. 7). This trend is opposite the oceanic crustal heat flux trend of decreasing heat flux with increasing age. We interpret the low heat flow as a result of active tectonic thickening between 10 and $25 \mathrm{~km}$ from the deformation front, which has produced the steep lower slope. Relatively low heat flow between 0 and $25 \mathrm{~km}$ from the toe of the wedge is also found in the Cascadia Margin off the coast of Vancouver and is shown to be caused by tectonic thickening effects (Hyndman et al., 1993). Local heat flow lows on Line 743 occur at $10 \mathrm{~km}, 18 \mathrm{~km}$, and $23 \mathrm{~km}$ from the deformation front, and may be produced by discrete thrusts beneath the local low. Discrete thrusts are not easily identified in the seismic section (Fig. 7), but there does appear to be a shallow dipping thrust that surfaces at the break in slope at $10 \mathrm{~km}$ from the deformation front.

South of the Darwin F.Z., the heat flow map indicates unusually high heat flow. The proximity of the young oceanic crust is reflected by the extremely high heat flow values of between $80 \mathrm{~mW} / \mathrm{m}^{2}$ along the upper slope and $200 \mathrm{~mW} / \mathrm{m}^{2}$ at the toe of the slope on Lines 745 and 748 . The $100-\mathrm{mW} / \mathrm{m}^{2}$ and $120-\mathrm{mW} / \mathrm{m}^{2}$ contours on the upper slope lie nearly parallel to the trend of the Chile Ridge, which suggests the heat flow is largely a result of conductive heat transfer from the oceanic crust, consistent with downhole temperature results (Brown et al., this volume). Heat flow increases seaward across the slope rather than decreasing as it does across Line 743 . Tectonic thickening probably has considerably less impact on the heat flow south of the Darwin F.Z., which is consistent with the smaller trench fill sediment and small accretionary complex south of the Darwin F.Z.

Finally, drilling data suggest a transition from conductive heat flow at Site 861 to a thermal structure produced by convective systems that involved vigorous fluid circulation near the toe of the wedge at Site 859 (Brown et al., this volume). The high heat flow contours at the toe of the trench $\left(>140 \mathrm{~mW} / \mathrm{m}^{2}\right)$ trend roughly along the deformation front rather than following constant age crust that parallels the Chile Ridge. This trend may reflect thermal effects associated with fluid circulation. The peak heat flow values on Lines 745 and 748 are both $\sim 750 \mathrm{~m}$ from the deformation front, while they differ by more than $3000 \mathrm{~m}$ in their distance from the spreading center. Alarge advective component near the toe is also consistent with differences between shallow thermal gradients measured by the heat flow probe and deeper gradients estimated from the BSR. Fluid circulation is presumed to be mainly lateral fluid flow out of sediments underthrust beneath the accretionary complex to the toe of the slope. In addition, fluids that have circulated within the oceanic crust and exit the crust beneath the accretionary complex may be directed to the toe of the wedge as they are expelled to the surface.

\section{CONCLUSIONS}

We interpret high heat flow south of the Darwin F.Z. as a result of three main factors: (1) a large heat flow component associated with the young oceanic crust subducting south of the Darwin F.Z., (2) advective heat transport from hydrothermal circulation focused near the toe of the slope, (3) little tectonic thickening activity. This contrasts with the heat flow north of the Darwin F.Z., where effects from recent thrusting appear to have a large impact on the heat flow pattern, 
depressing heat flow across the lower slope to the toe of the accretionary complex.

\section{ACKNOWLEDGMENTS}

We thank Jean Paul Foucher and Marcus Langseth for their reviews of this manuscript. This work was supported from USSAC grant 14120672. UTIG contribution number 1073.

\section{REFERENCES $*$}

Bangs, N., Cande, S.C., Lewis, S.D., and Miller, J., 1992. Structural framework of the Chile Margin at the Chile Ridge collision zone. In Behrmann, J.H., Lewis, S.D., Musgrave, R.J., et al., Proc. ODP, Init. Repts., 141: College Station. TX (Ocean Drilling Program), 11-21.

Behrmann, J.H., Lewis, S.D., Musgrave, R.J., et al., 1992. Proc, ODP, Init. Repts., 141: College Station, TX (Ocean Drilling Program).

Cande, S.C., Leslie, R.B., Parra, J.C., and Hobart, M., 1987. Interaction between the Chile Ridge and Chile Trench: geophysical and geothermal evidence. J. Geophys. Res., 92:495-520.

Davis, E.E., Hyndman, R.D., and Villinger, H., 1990. Rates of fluid expulsion across the northern Cascadia accretionary prism: constraints from new heat flow and multichannel seismic reflection data. J. Geophys. Res., 95:88698889.

Ferguson, I.J., Westbrook, G.K., Langseth, M.G., and Thomas, G.P., 1993. Heat flow and thermal models of the Barbados Ridge accretionary complex. J. Geophys. Res., 98:4121-4142.

Hyndman, R.D., Foucher, J.P., Yamano, M., Fisher, A., Berner, U., Brückmann, W., Byrne, T., Chabernaud, T., Firth, J.V., Gamo, T., Gieskes, J.M., Hill, I.A., Karig, D.E., Kastner, M., Kato, Y., Lallemand, S., Lau, R., Maltman, A.J., Moore, G.F., Moran, K., Olafsson, G., Owens, W.H., Pickering, K., Siena, F., Taira, A., Taylor, E., Underwood, M.B., Wilkinson, C., and Zhang, J., 1992. Deep sea bottom-simulating-reflectors: calibration of the base of the hydrate stability field as used for heat flow estimates. Earth Planet. Sci. Lett., 109:289-301.

Hyndman, R.D., Wang, K., Yuan, T., and Spence, G.D., 1993. Tectonic sediment thickening, fluid expulsion, and the thermal regime of subduction zone accretionary prisms: the Cascadia margin off Vancouver Island. $J$. Geophys. Res., 98:21865-21876.

Kvenvolden, K.A., and Barnard, L.A., 1983. Hydrates of natural gas in continental margins. In Watkins, J.S., and Drake, C.L. (Eds.), Studies in Continental Margin Geology. AAPG, 34:631-640.

Langseth, M.G., Westbrook, G.K., and Hobart, M., 1990. Contrasting geothermal regimes of the Barbados Ridge accretionary complex. J. Geophys. Res., 95:8829-8843.

Macleod, M.K., 1982. Gas hydrates in ocean bottom sediments. AAPG Bull., 66:2649-2662.

Minshull, T., and White, R., 1989. Sediment compaction and fluid migration in the Makran accretionary prism. J. Geophys. Res., 94:7387-7402.

Parsons, B., and Sclater, J.G., 1977. An analysis of the variation of ocean floor bathymetry and heat flow with age. J. Geophys. Res., 82:803-829.

Shipley, T.H., Houston, M.H., Buffler, R.T., Shaub, F.J., McMillen, K.J., Ladd, J.W., and Worzel, J.L., 1979. Seismic evidence for widespread possible gas hydrate horizons on continental slopes and rises. AAPG Bull., 63:2204-2213.

Yamano, M., Uyeda, S., Aoki, Y., and Shipley, T.H., 1982. Estimates of heat flow derived from gas hydrates. Geology, 10:339-343.

Abbreviations for names of organizations and publications in ODP reference lists follow the style given in Chemical Abstracts Service Source Index (published by American Chemical Society).

Date of initial receipt: 5 October 1993

Date of acceptance: 22 July 1994

Ms 141SR-043 